\title{
The Synthesis and Physical Properties of Magnesium Borate Mineral of Admontite Synthesized from Sodium Borates
}

\author{
Azmi Seyhun Kipcak, ${ }^{1}$ Meral Yildirim, ${ }^{1}$ Sureyya Aydin Yuksel, ${ }^{2}$ \\ Emek Moroydor Derun, ${ }^{1}$ and Sabriye Piskin ${ }^{1}$ \\ ${ }^{1}$ Department of Chemical Engineering, Faculty of Chemical and Metallurgical Engineering, Yildiz Technical University, \\ Davutpasa Campus, Davutpasa Street No. 127, Esenler, 34210 Istanbul, Turkey \\ ${ }^{2}$ Department of Physics, Faculty of Arts and Science, Yildiz Technical University, Davutpasa Campus, \\ Davutpasa Street No. 127, Esenler, 34210 Istanbul, Turkey
}

Correspondence should be addressed to Emek Moroydor Derun; moroydor@gmail.com

Received 17 April 2014; Revised 16 July 2014; Accepted 18 July 2014; Published 13 August 2014

Academic Editor: You Song

Copyright (C) 2014 Azmi Seyhun Kipcak et al. This is an open access article distributed under the Creative Commons Attribution License, which permits unrestricted use, distribution, and reproduction in any medium, provided the original work is properly cited.

\begin{abstract}
Magnesium borates are significant compounds due to their advanced mechanical and thermal durability properties. This group of minerals can be used in ceramic industry, in detergent industry, and as neutron shielding material, phosphor of thermoluminescence by dint of their extraordinary specialties. In the present study, the synthesis of magnesium borate via hydrothermal method from sodium borates and physical properties of synthesized magnesium borate minerals were investigated. The characterization of the products was carried out by X-ray diffraction (XRD), Fourier transform infrared (FT-IR) and Raman spectroscopies, and differential thermal analysis and thermal gravimetry (DTA/TG). The surface morphology was examined by scanning electron microscopy $(\mathrm{SEM}) . \mathrm{B}_{2} \mathrm{O}_{3}$ content was determined through titration. The electrical resistivity/conductivity properties of products were measured by Picoammeter Voltage Source. UV-vis spectrometer was used to investigate optical absorption characteristics of synthesized minerals in the range 200-1000 nm at room temperature. XRD results identified the synthesized borate minerals as admontite $\left[\mathrm{MgO}\left(\mathrm{B}_{2} \mathrm{O}_{3}\right)_{3} \cdot 7\left(\mathrm{H}_{2} \mathrm{O}\right)\right]$ with code number "01-076-0540" and mcallisterite $\left[\mathrm{Mg}_{2}\left(\mathrm{~B}_{6} \mathrm{O}_{7}(\mathrm{OH})_{6}\right)_{2} \cdot 9\left(\mathrm{H}_{2} \mathrm{O}\right)\right]$ with code number "01-070-1902." The FT-IR and Raman spectra of the obtained samples were similar with characteristic magnesium borate bands. The investigation of the SEM images remarked that both nano- and microscale minerals were produced. The reaction yields were between 75.1 and $98.7 \%$.
\end{abstract}

\section{Introduction}

Magnesium borates are considerable borate minerals by virtue of their high heat resistance, light weight, high elasticity coefficient, birefringent crystal structure, anticorrosion, and antiwear properties [1-4]. Owing to these properties, magnesium borates have extensive usage area and application potentials. Magnesium borates can be used in ceramic industry, in superconducted material production, in detergent composition, in friction reducing additive manufacture, in fluorescent discharge lamps as luminescent material, in ferroelastic material production, in cathode ray tube screens, in X-ray screens, and as thermoluminescent phosphor [5-10]. And also magnesium borates have great potential in areas of electronic ceramics reinforcement, semiconductor material synthesis, and plastics or aluminum/magnesium matrix alloy production $[11,12]$.

The production methods of magnesium borate minerals can be divided into two by hydrothermal and thermal methods [13]. In previous studies different types of magnesium borate minerals were synthesized. For the syntheses different starting materials were used. $\mathrm{MgO}$ and $\mathrm{H}_{3} \mathrm{BO}_{3}$ were used by Dou et al. [1] to synthesis magnesium borate types of $\mathrm{MgO} \cdot 3 \mathrm{~B}_{2} \mathrm{O}_{3} \cdot 7 \mathrm{H}_{2} \mathrm{O}$ and $2 \mathrm{MgO} \cdot \mathrm{B}_{2} \mathrm{O}_{3} \cdot \mathrm{H}_{2} \mathrm{O}$. Li et al. [2] prepared $\mathrm{Mg}_{2} \mathrm{~B}_{2} \mathrm{O}_{5}$ by the raw materials of $\mathrm{MgBr}_{2} \cdot 6 \mathrm{H}_{2} \mathrm{O}$ and $\mathrm{NaBH}_{4}$. Zhu et al. [14] used $\mathrm{MgCl}_{2} \cdot 6 \mathrm{H}_{2} \mathrm{O}, \mathrm{H}_{3} \mathrm{BO}_{3}$, and $\mathrm{NaOH}$ to synthesize $\mathrm{MgBO}_{2}(\mathrm{OH}) \cdot \mathrm{Mg}(\mathrm{OH})_{2}$ and $\mathrm{H}_{3} \mathrm{BO}_{3}$ were used by Elssfah et al. [15] for the purpose of producing 
$\mathrm{Mg}_{2} \mathrm{~B}_{2} \mathrm{O}_{5} \cdot \mathrm{MgO}, \mathrm{BI}_{3}$, and $\mathrm{H}_{3} \mathrm{BO}_{3}$ were selected as starting materials for synthesis of $\mathrm{Mg}_{2} \mathrm{~B}_{2} \mathrm{O}_{5}$ by Li et al. [16]. Wang et al. [17] used $\mathrm{MgNO}_{3} \cdot 6 \mathrm{H}_{2} \mathrm{O}$ and $\mathrm{Na}_{2} \mathrm{~B}_{4} \mathrm{O}_{7} \cdot 10 \mathrm{H}_{2} \mathrm{O}$ for obtaining magnesium borate nanowires. $2 \mathrm{MgO} \cdot 2 \mathrm{~B}_{2} \mathrm{O}_{3} \cdot \mathrm{MgCl}_{2} \cdot 14 \mathrm{H}_{2} \mathrm{O}$ and $\mathrm{H}_{3} \mathrm{BO}_{3}$ were chosen by Zhihong and Mancheng [18] for preparation of $2 \mathrm{MgO} \cdot \mathrm{B}_{2} \mathrm{O}_{3} \cdot \mathrm{H}_{2} \mathrm{O}$.

The specific type of magnesium borate mineral, namely, admontite, was synthesized from $\mathrm{MgO}$ and $\mathrm{H}_{3} \mathrm{BO}_{3}$ at $100^{\circ} \mathrm{C}$ for the reaction times of 120 and 240 minutes by Derun et al. [19]. Also at their other study, Derun and Senberber [20] synthesized pure mcallisterite by using the same raw materials of $\mathrm{MgO}$ and $\mathrm{H}_{3} \mathrm{BO}_{3}$.

The common point to all previous magnesium borate syntheses by hydrothermal method was high reaction temperatures $\left(\geq 100^{\circ} \mathrm{C}\right)$ and extended reaction times, where in literature hydrothermal syntheses are frequently driven in a temperature range of $100-220^{\circ} \mathrm{C}$ [4]. Furthermore the crystallinities of the obtained minerals were not at the desired levels.

Considering different studies about preparation of magnesium borate in this study, in order to obtain the magnesium borates below $100^{\circ} \mathrm{C}$ reaction temperature and 120 minutes of reaction time, different combinations and mole ratios of $\mathrm{MgCl}_{2} \cdot 6 \mathrm{H}_{2} \mathrm{O}, \mathrm{H}_{3} \mathrm{BO}_{3}, \mathrm{~B}_{2} \mathrm{O}_{3}, \mathrm{Na}_{2} \mathrm{~B}_{4} \mathrm{O}_{7} \cdot 5 \mathrm{H}_{2} \mathrm{O}$, and $\mathrm{Na}_{2} \mathrm{~B}_{4} \mathrm{O}_{7} \cdot 10 \mathrm{H}_{2} \mathrm{O}$ were used as raw materials in the hydrothermal synthesis. The mole ratios of raw materials were decided from previous experiments [21]. The main originality of the study is to produce magnesium borate compounds at lower temperatures and shorter reaction times, which leads to less energy consumption and time for a green chemistry approach. Another novelty of this study is the investigation and comparison of the electrical and optical characteristics of bulk and nanowires magnesium borate crystal that were investigated in the literature $[16,22,23]$. The bulk magnesium borate crystal has a wide optical band gap of $5.44 \mathrm{eV}$ according to theoretical calculation [22].

Synthesized magnesium borate minerals were characterized by using X-ray diffraction (XRD), Fourier transform infrared (FT-IR) spectroscopy, Raman spectroscopy, scanning electron microscopy (SEM), and differential thermal analysis and thermal gravimetry (DTA/TG). Electrical and optical properties of the different magnesium borate minerals were investigated with picoammeter voltage source and UVvis spectrometer techniques, respectively.

\section{Materials and Methods}

2.1. Preparation and Characterization of the Raw Materials. Magnesium chloride hexahydrate $\left(\mathrm{MgCl}_{2} \cdot 6 \mathrm{H}_{2} \mathrm{O}\right)$ was obtained from Merck Chemicals at minimum purity of $98 \%$ and particle size below $70 \mu \mathrm{m}$. Other reactants were retrieved from Bandirma Boron Works with a particle size below $1 \mathrm{~mm}$. Among these raw materials boric acid $\left(\mathrm{H}_{3} \mathrm{BO}_{3}\right)$, tincalconite $\left(\mathrm{Na}_{2} \mathrm{~B}_{4} \mathrm{O}_{7} \cdot 5 \mathrm{H}_{2} \mathrm{O}\right)$, and borax $\left(\mathrm{Na}_{2} \mathrm{~B}_{4} \mathrm{O}_{7} \cdot 10 \mathrm{H}_{2} \mathrm{O}\right)$ have a minimum purity of $99.9 \%$ and boron oxide $\left(\mathrm{B}_{2} \mathrm{O}_{3}\right)$ has a minimum purity of $98 \%$. Since the $\mathrm{MgCl}_{2} \cdot 6 \mathrm{H}_{2} \mathrm{O}$ particle size was fine it was not pretreated, but other raw materials were processed by crushing, grinding through agate mortar (Retsch RM200), and sieving through Fritsch shaker sieve to reduce particle size down to below $70 \mu \mathrm{m}$. Then reactants were identified in Philips PANalytical XRD (step: $0.030^{\circ}$, time for step: $0.50 \mathrm{~s}$, scan speed: $0.006^{\circ} / \mathrm{s}$, and range: $7-90^{\circ}$ ) at $45 \mathrm{kV}$ and $40 \mathrm{~mA}$ through the $\mathrm{X}$-rays obtained in the $\mathrm{Cu}-\mathrm{K} \alpha$ tube.

2.2. Magnesium Borate Synthesis. Some preliminary analyses were carried out using different molar ratios of $\mathrm{MgCl}_{2} \cdot 6 \mathrm{H}_{2} \mathrm{O}: \mathrm{Na}_{2} \mathrm{~B}_{4} \mathrm{O}_{7} \cdot 5 \mathrm{H}_{2} \mathrm{O}: \mathrm{H}_{3} \mathrm{BO}_{3}(\mathrm{Mc}: \mathrm{T}: \mathrm{H})$ and the use of a molar Mc: $\mathrm{T}: \mathrm{H}$ ratio of $1: 1: 3$ throughout the analysis was selected for further experiments [19]. The expected reaction schemes are shown in (1)-(4):

$$
\begin{aligned}
& \mathrm{MgCl}_{2} \cdot 6 \mathrm{H}_{2} \mathrm{O}+\mathrm{Na}_{2} \mathrm{~B}_{4} \mathrm{O}_{7} \cdot 5 \mathrm{H}_{2} \mathrm{O}+3 \mathrm{H}_{3} \mathrm{BO}_{3} \\
& +x \mathrm{H}_{2} \mathrm{O} \longrightarrow \mathrm{MgO}\left(\mathrm{B}_{2} \mathrm{O}_{3}\right)_{3} \cdot 7 \mathrm{H}_{2} \mathrm{O}+2 \mathrm{NaCl} \\
& +\mathrm{H}_{3} \mathrm{BO}_{3}+y \mathrm{H}_{2} \mathrm{O} \\
& \mathrm{MgCl}_{2} \cdot 6 \mathrm{H}_{2} \mathrm{O}+\mathrm{Na}_{2} \mathrm{~B}_{4} \mathrm{O}_{7} \cdot 5 \mathrm{H}_{2} \mathrm{O} \\
& +\frac{3}{2} \mathrm{~B}_{2} \mathrm{O}_{3}+x \mathrm{H}_{2} \mathrm{O} \longrightarrow \mathrm{MgO}\left(\mathrm{B}_{2} \mathrm{O}_{3}\right)_{3} \cdot 7 \mathrm{H}_{2} \mathrm{O} \\
& +2 \mathrm{NaCl}+\mathrm{H}_{3} \mathrm{BO}_{3}+y \mathrm{H}_{2} \mathrm{O} \\
& \mathrm{MgCl}_{2} \cdot 6 \mathrm{H}_{2} \mathrm{O}+\mathrm{Na}_{2} \mathrm{~B}_{4} \mathrm{O}_{7} \cdot 10 \mathrm{H}_{2} \mathrm{O} \\
& +3 \mathrm{H}_{3} \mathrm{BO}_{3}+x \mathrm{H}_{2} \mathrm{O} \longrightarrow \mathrm{MgO}\left(\mathrm{B}_{2} \mathrm{O}_{3}\right)_{3} \cdot 7 \mathrm{H}_{2} \mathrm{O} \\
& +2 \mathrm{NaCl}+\mathrm{H}_{3} \mathrm{BO}_{3}+y \mathrm{H}_{2} \mathrm{O} \\
& \mathrm{MgCl}_{2} \cdot 6 \mathrm{H}_{2} \mathrm{O}+\mathrm{Na}_{2} \mathrm{~B}_{4} \mathrm{O}_{7} \cdot 10 \mathrm{H}_{2} \mathrm{O} \\
& +\frac{3}{2} \mathrm{~B}_{2} \mathrm{O}_{3}+x \mathrm{H}_{2} \mathrm{O} \longrightarrow \mathrm{MgO}\left(\mathrm{B}_{2} \mathrm{O}_{3}\right)_{3} \cdot 7 \mathrm{H}_{2} \mathrm{O} \\
& +2 \mathrm{NaCl}+\mathrm{H}_{3} \mathrm{BO}_{3}+y \mathrm{H}_{2} \mathrm{O}
\end{aligned}
$$

The distilled water used in the experiments was obtained from a "Human Power I+" water treatment system and had a conductivity value of $18.3 \mathrm{~m} \Omega \cdot \mathrm{cm}$. The reaction temperatures and reaction times were selected between $60-100^{\circ} \mathrm{C}$ and $30-240 \mathrm{~min}$. The experiments were carried out in a glass reactor and the reaction temperature was set as constant by a temperature control unit.

At the end of the selected reaction times the solution was put in an incubator maintained at $40^{\circ} \mathrm{C}$ until the excess water evaporated and magnesium borate minerals were crystallized. Then crystallized magnesium borate minerals were washed with pure (96\%) ethanol three times to separate unreacted components and byproduct of $\mathrm{NaCl}$. Washed samples were dried in an incubator maintained at $40^{\circ} \mathrm{C}$ again. The experimental method was shown in Figure 1.

2.3. Magnesium Borate Characterization Studies. Synthesized magnesium borates were subjected to XRD, FT-IR spectroscopy, and Raman spectroscopy. The parameters used in XRD were the same as those used in Section 2.1; only the range of the patterns was set between 7 and $60^{\circ}$, since the characteristic peaks of magnesium borates are seen in that range. 


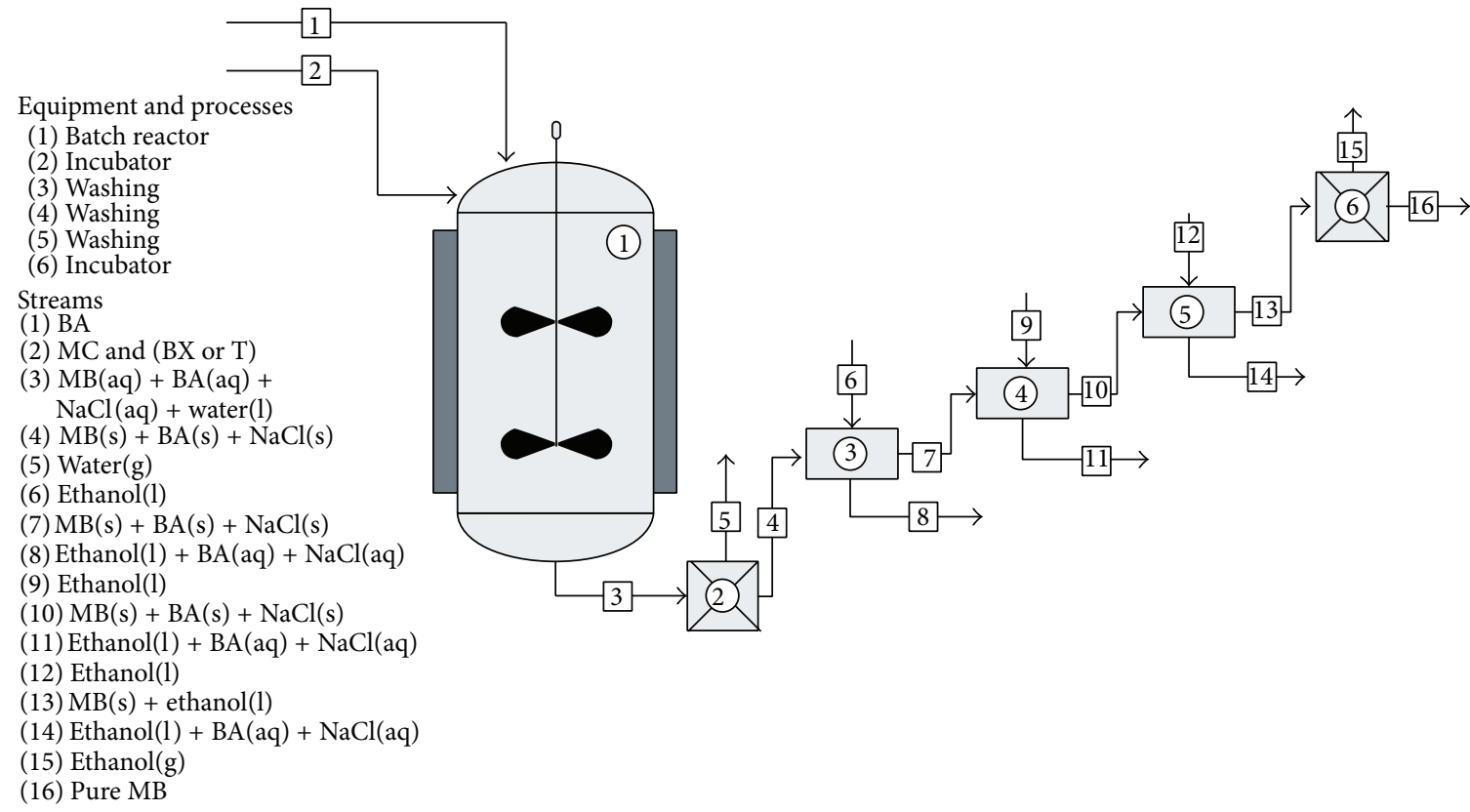

\author{
Abbreviations \\ BA: boric acid \\ MC: magnesium chloride hexahydrate \\ T: tincalconite \\ s: Solid, aq: Aqueous \\ BX: borax \\ 1: Liquid, g: Gas
}

FIGURE 1: Schematic experimental method.

The characteristic peaks of borate compounds were given in the range of $1500-500 \mathrm{~cm}^{-1}$ [24] so the spectrum ranges in FT-IR and Raman were selected as $1800 \mathrm{~cm}^{-1}-650 \mathrm{~cm}^{-1}$ and $1800 \mathrm{~cm}^{-1}-250 \mathrm{~cm}^{-1}$, respectively. Also no peak above $1800 \mathrm{~cm}^{-1}$ was observed in either one of the spectral analyses.

The morphological features of materials, including their structure, morphology, phase, shape, size, and distribution, are affected by their physical and chemical properties [25]. CamScan Apollo 300 Field-Emission SEM was used to observe the surface textures and particle sizes of the synthesized magnesium borate minerals at $20 \mathrm{kV}$. The detector used was back scattering electron (BEI) and the magnification was set to 10000 .

The commercial values of the boron minerals are evaluated from the $\mathrm{B}_{2} \mathrm{O}_{3}$ content of these minerals. This analysis was carried out using the method reported by Derun et al. [19].

Thermal analysis of a pure admontite selected from the $\mathrm{XRD}$ results was studied between the temperature range of $20-720^{\circ} \mathrm{C}$ with a Perkin Elmer Diamond DTA/TG with a heating rate of $10^{\circ} \mathrm{C} / \mathrm{min}$ in an inert (nitrogen) atmosphere.

In order to investigate and characterize the product obtained after the thermal analysis, admontite mineral was placed in a Protherm MOS 180/4 high temperature furnace with $10^{\circ} \mathrm{C} / \mathrm{min}$ temperature increment to a maximum temperature of $720^{\circ} \mathrm{C}$ in nitrogen flowing $(5 \mathrm{~mL} / \mathrm{min})$ atmosphere. After the thermal conversion, the product was analyzed by XRD with the same parameters given in Section 2.3.
Yield analysis was also carried out using the method reported by Derun et al. [19] where $\mathrm{MgCl}_{2} \cdot 6 \mathrm{H}_{2} \mathrm{O}$ was identified as the key component. Experiments were carried out in triplicate in three pure admontite minerals, which have the highest XRD scores in order to calculate the average yields and the standard deviations. The yield calculation of the biphasic samples was carried out based on the phase with the highest molecular weight.

The number of moles of product at the final stage, $N_{D}$, was divided by the number of consumed moles of the key reactant $A$ to calculate the overall yield, $Y_{D}(5)$. The number of moles of $A$ that was consumed was calculated using the initial $\left(N_{A 0}\right)$ and the final $\left(N_{A}\right)$ moles of the reactant. The equation then becomes as follows for a batch system $[19,26]$ :

$$
Y_{D}=\frac{N_{D}}{N_{A 0}+N_{A}} .
$$

\subsection{Electrical and Optical Properties of Magnesium Borates.} The synthesized magnesium borate compounds were pressed under pressure of $30 \mathrm{MPa}$ into pellets with $13 \mathrm{~mm}$ diameters and $0.4 \mathrm{~mm}$ thickness. Electrical resistivity measurement of synthesized magnesium borate compounds which are coded with "Mc-Bx-B-60-240," "Mc-T-B-80-60," and "Mc-Bx-H100-60" was carried out by standard current voltage measurement at room temperature using Keithley 6487 in dark with thermally evaporated silver contacts on both surfaces of pellets. The optical absorbance spectrum of magnesium 
TABLE 1: XRD scores of the synthesized magnesium borate minerals.

\begin{tabular}{|c|c|c|c|c|c|c|c|c|c|}
\hline \multirow{2}{*}{$\begin{array}{l}\text { Reaction } \\
\text { temperature }\left({ }^{\circ} \mathrm{C}\right)\end{array}$} & \multirow{2}{*}{$\begin{array}{l}\text { Reaction } \\
\text { time } \\
(\mathrm{min})\end{array}$} & \multicolumn{2}{|c|}{ Mc-T-H ${ }^{*}$} & \multicolumn{2}{|c|}{ Mc-T-B* } & \multicolumn{2}{|c|}{$\mathrm{Mc}-\mathrm{Bx}-\mathrm{H}^{*}$} & \multicolumn{2}{|c|}{ Mc-Bx-B* } \\
\hline & & Admontite & Mcallisterite & Admontite & Mcallisterite & Admontite & Mcallisterite & Admontite & Mcallisterite \\
\hline \multirow{4}{*}{60} & 30 & 68 & 64 & 59 & 64 & 67 & - & 60 & - \\
\hline & 60 & 62 & 68 & 66 & 52 & 68 & - & 63 & - \\
\hline & 120 & 65 & 35 & 59 & 58 & 64 & 46 & 68 & - \\
\hline & 240 & 67 & 55 & 61 & 48 & 63 & - & 71 & - \\
\hline \multirow{4}{*}{80} & 30 & 61 & 76 & 66 & 40 & 64 & - & 65 & - \\
\hline & 60 & 65 & 54 & 70 & - & 65 & - & 64 & 56 \\
\hline & 120 & 56 & 54 & 62 & 56 & 57 & - & 60 & - \\
\hline & 240 & 49 & 60 & 63 & 45 & 65 & - & 65 & - \\
\hline \multirow{4}{*}{100} & 30 & 45 & 80 & 47 & 79 & 63 & - & 62 & - \\
\hline & 60 & 46 & 79 & 49 & 81 & 70 & - & 58 & 31 \\
\hline & 120 & 44 & 80 & 39 & 81 & 56 & 44 & 61 & 40 \\
\hline & 240 & 49 & 74 & 48 & 60 & 62 & - & 64 & 17 \\
\hline
\end{tabular}

${ }^{*} \mathrm{Mc}: \mathrm{MgCl}_{2} \cdot 6 \mathrm{H}_{2} \mathrm{O}, \mathrm{T}: \mathrm{Na}_{2} \mathrm{~B}_{4} \mathrm{O}_{5}(\mathrm{OH})_{4} \cdot 3 \mathrm{H}_{2} \mathrm{O}, \mathrm{H}: \mathrm{H}_{3} \mathrm{BO}_{3}, \mathrm{~B}: \mathrm{B}_{2} \mathrm{O}_{3}$, and $\mathrm{Bx}: \mathrm{Na}_{2} \mathrm{~B}_{4} \mathrm{O}_{5}(\mathrm{OH})_{4} \cdot 8 \mathrm{H}_{2} \mathrm{O}$.

borate compounds was taken by Perkin Elmer UV-vis spectrophotometer at room temperature. In this measurement the magnesium borate compounds were dispersed in $\mathrm{HCl}$ solution in quartz tube $(1 \mathrm{~cm} \times 1 \mathrm{~cm})$.

\section{Results}

3.1. Results of the Raw Material Characterization. Magnesium source of $\mathrm{MgCl}_{2} \cdot 6 \mathrm{H}_{2} \mathrm{O}$ was determined as "bischofite" (reference code: 01-077-1268). Sodium-boron source of $\mathrm{Na}_{2} \mathrm{~B}_{4} \mathrm{O}_{7} \cdot 5 \mathrm{H}_{2} \mathrm{O}$ was determined as "tincalconite" (reference code: 01-079-1529) and another sodium-boron source of $\mathrm{Na}_{2} \mathrm{~B}_{4} \mathrm{O}_{7} \cdot 5 \mathrm{H}_{2} \mathrm{O}$ was found as the mixture of both "borax" (reference code: 01-075-1078) and "tincalconite" (reference code: 01-079-1529). Boron sources of $\mathrm{H}_{3} \mathrm{BO}_{3}$ were determined as "sassolite" (reference code: 01-073-2158) and $\mathrm{B}_{2} \mathrm{O}_{3}$ was determined as the mixture of two types of "boron oxide" (reference codes: 00-006-0297 and 01-088-2485).

3.2. XRD Results of the Synthesized Magnesium Borates. Synthesized minerals XRD results were given in Table 1. It is seen from the results that the synthesized products were admontite $\left[\mathrm{MgO}\left(\mathrm{B}_{2} \mathrm{O}_{3}\right)_{3} \cdot 7\left(\mathrm{H}_{2} \mathrm{O}\right)\right]$ and mcallisterite $\left[\mathrm{Mg}_{2}\left(\mathrm{~B}_{6} \mathrm{O}_{7}(\mathrm{OH})_{6}\right)_{2} \cdot 9\left(\mathrm{H}_{2} \mathrm{O}\right)\right]$. The XRD patterns of three pure admontite minerals, which have the highest XRD scores, were represented in Figure 2.

As it is seen from Figure 2, the five major characteristic peaks of admontite mineral are seen at all three minerals at around $7^{\circ}, 17^{\circ}, 23^{\circ}, 29^{\circ}$, and $34^{\circ}$. The crystallographic data of synthesized magnesium borates are given in Table 2 .

The obtained products for Mc-T-H experimental setup were formed in two distinct phases at all reaction temperatures and times. The higher mcallisterite scores were reached at increasing reaction temperatures. For Mc-T-B experimental setup, the obtained products were formed in two distinct phases the same as Mc-T-H set of experiment at all reaction temperatures and times except at $80^{\circ} \mathrm{C}$ and
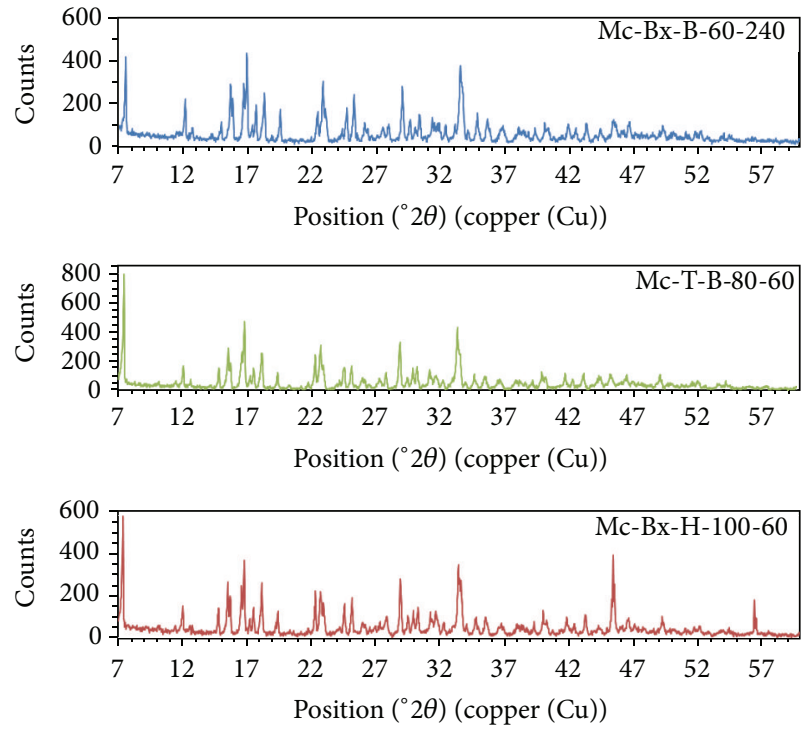

FIGURE 2: XRD patterns of pure admontite minerals.

for the reaction time of 60 minutes. The pure admontite which had the highest crystal score was synthesized at $80^{\circ} \mathrm{C}$ after 60 minutes. Most of the synthesized minerals were pure admontite for $\mathrm{Mc}-\mathrm{Bx}-\mathrm{H}$ experimental setup apart from synthesis at $60^{\circ} \mathrm{C}$ and $100^{\circ} \mathrm{C}$ when the reaction time was 120 minutes. The highest admontite crystal score was achieved at $100^{\circ} \mathrm{C}$ after 60 minutes. At Mc-Bx-B experimental setup, for all reaction times, the obtained minerals which were produced at $60^{\circ} \mathrm{C}$ were pure admontite. Also, the highest admontite crystal score for all experimental setups was reached after the reaction of 240 minutes at $60^{\circ} \mathrm{C}$.

3.3. FT-IR and Raman Spectral Analysis Results for the Synthesized Products. The FT-IR and Raman spectra of the synthesized magnesium borate minerals were very similar 
TABLE 2: Crystallographic data of synthesized magnesium borates.

\begin{tabular}{lcc}
\hline $\begin{array}{l}\text { Mineral } \\
\text { name }\end{array}$ & Admontite & Mcallisterite \\
\hline $\begin{array}{l}\text { Pdf number } \\
\text { Chemical }\end{array}$ & $01-076-0540$ & $01-070-1902$ \\
formula & $\mathrm{MgO}\left(\mathrm{B}_{2} \mathrm{O}_{3}\right)_{3} \cdot 7\left(\mathrm{H}_{2} \mathrm{O}\right)$ & $\mathrm{Mg}_{2}\left(\mathrm{~B}_{6} \mathrm{O}_{7}(\mathrm{OH})_{6}\right)_{2} \cdot 9\left(\mathrm{H}_{2} \mathrm{O}\right)$ \\
$\begin{array}{l}\text { Molecular } \\
\text { weight }\end{array}$ & & \\
(g/mole) & 375.27 & 768.56 \\
Crystal & & \\
system & Monoclinic & Rhombohedral \\
Space group & $\mathrm{P} 21 / \mathrm{c}($ number 14$)$ & Pr3c (number 167) \\
$a(\AA)$ & 12.6610 & 11.5490 \\
$b(\AA)$ & 10.0910 & 11.5490 \\
$c(\AA)$ & 11.3220 & 35.5670 \\
$\alpha\left(^{\circ}\right)$ & 90.00 & 90.00 \\
$\beta\left(^{\circ}\right)$ & 109.60 & 90.00 \\
$\gamma\left(^{\circ}\right)$ & 90.00 & 120.00 \\
$z$ & 4.00 & 6.00 \\
Density & & 1.86 \\
$(\mathrm{calculated})$ & 1.83 & \\
$\left(\mathrm{~g} \cdot \mathrm{cm}^{-3}\right)$ & &
\end{tabular}

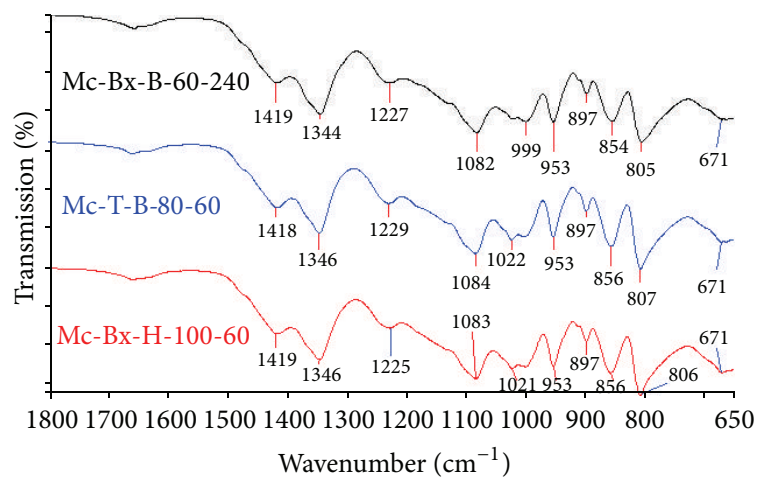

FIGURE 3: FT-IR spectra of pure admontite minerals.

and were also in accordance with Yongzhong et al. [24]. FTIR and Raman spectra of pure admontite minerals are given in Figures 3 and 4, respectively.

In the FT-IR spectrum, asymmetric stretching of the three-coordinate boron $\left[v_{\text {as }}\left(\mathrm{B}_{(3)}-\mathrm{O}\right)\right]$ was observed in the range of $1419 \mathrm{~cm}^{-1}-1344 \mathrm{~cm}^{-1}$. The peak at between $1229 \mathrm{~cm}^{-1}$ and $1225 \mathrm{~cm}^{-1}$ corresponded to bending of $\mathrm{B}-\mathrm{O}-\mathrm{H}$ $[\delta(\mathrm{B}-\mathrm{O}-\mathrm{H})]$ and the asymmetric stretching of the fourcoordinate boron $\left[v_{\text {as }}\left(\mathrm{B}_{(4)}-\mathrm{O}\right)\right]$ was observed in the range of $1084 \mathrm{~cm}^{-1}-999 \mathrm{~cm}^{-1}$. Between the range of $953 \mathrm{~cm}^{-1}$ and $897 \mathrm{~cm}^{-1}$ symmetric stretching of the three-coordinate boron $\left[\nu_{s}\left(\mathrm{~B}_{(3)}-\mathrm{O}\right)\right]$ was observed. The peaks between $856 \mathrm{~cm}^{-1}$ and $805 \mathrm{~cm}^{-1}$ coincided with symmetric stretching of the fourcoordinate boron $\left[\nu_{s}\left(\mathrm{~B}_{(4)}-\mathrm{O}\right)\right]$. Bending of three-coordinate boron $\left[\delta\left(\mathrm{B}_{(3)}-\mathrm{O}\right)\right]$ was observed at around $671 \mathrm{~cm}^{-1}$.

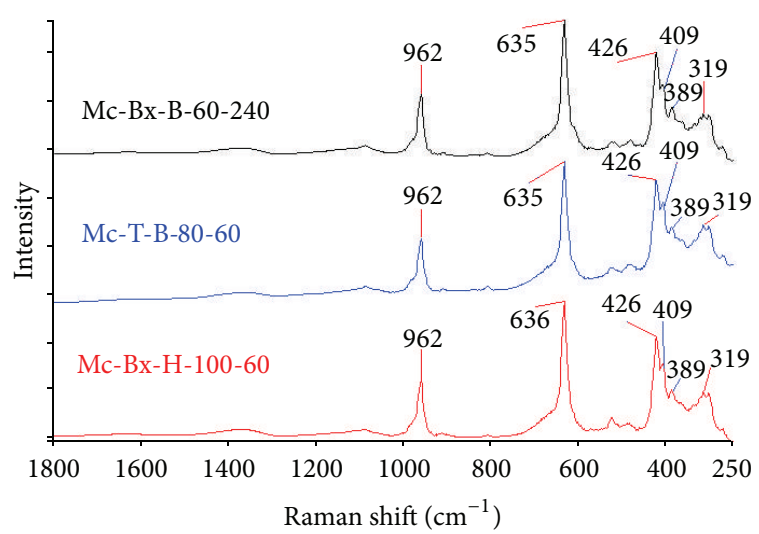

FIGURE 4: Raman spectra of pure admontite minerals.

In the Raman spectrum, the band in the region of $952 \mathrm{~cm}^{-1}$ was asymmetric stretching of the four-coordinate boron $\left[v_{\mathrm{as}}\left(\mathrm{B}_{(4)}-\mathrm{O}\right)\right]$; the bands at around $636 \mathrm{~cm}^{-1}-635 \mathrm{~cm}^{-1}$ were associated with $\nu_{p}\left[\mathrm{~B}_{6} \mathrm{O}_{7}(\mathrm{OH})_{6}\right]^{2-} / \nu_{p}\left[\mathrm{~B}_{3} \mathrm{O}_{3}(\mathrm{OH})_{4}\right]^{-}$. The peaks at and below $426 \mathrm{~cm}^{-1}$ belonged to bending of four-coordinate boron $\left[\delta\left(\mathrm{B}_{(4)}-\mathrm{O}\right)\right]$.

3.4. $\mathrm{B}_{2} \mathrm{O}_{3}$ Content of the Synthesized Minerals. The $\mathrm{B}_{2} \mathrm{O}_{3}$ analysis results of the synthesized magnesium borate minerals are given in Table 3 . The $\mathrm{B}_{2} \mathrm{O}_{3}$ content was calculated between $40.00 \%$ and $55.39 \%$. In the synthesized pure admontite minerals of coded "Mc-Bx-B-60-240," "Mc-T-B-80-60," and "Mc-Bx-H-100-60," $\mathrm{B}_{2} \mathrm{O}_{3}$ contents were found as $52.03 \pm$ $1.59 \%, 54.04 \pm 1.37 \%$, and $51.92 \pm 2.28 \%$, respectively. Since $\mathrm{B}_{2} \mathrm{O}_{3}$ content of the admontite mineral is $55.66 \%$ [19], the results were close to the literature value.

3.5. Surface Morphology and Particle Size of the Synthesized Admontite. Since the pure admontite minerals XRD scores were very close to each other (Mc-Bx-B-60-240: 71, Mc-TB-80-60: 70, and Mc-Bx-B-100-60: 70), only "Mc-T-B-80-60" and "Mc-Bx-B-100-60" had been subjected to SEM analyses because of the low reaction times. SEM surface morphology and the particle size of admontite were given in Figure 5.

Obtained admontite crystals were layered, agglomerated, locally porous, smooth edged in "Mc-T-B-80-60", and sharp edged in "Mc-Bx-B-100-60." The size distribution, though varying due to the agglomerated structure, of admontite, of which "Mc-T-B-80-60" and "Mc-Bx-B-100-60" coded minerals particle sizes, was found between $2.04 \mu \mathrm{m}-283.74 \mathrm{~nm}$ and $2.38 \mu \mathrm{m}-207.10 \mathrm{~nm}$, respectively.

3.6. Thermal Analysis Results. TG and DTG analyses of a selected (moderate reaction temperature and low reaction time) admontite which has a code of "Mc-T-B-80-60" are shown in Figure 6.

The analysis showed that three endothermic peaks occurred. The first peak that occurred between the temperatures of 40 and $59.47^{\circ} \mathrm{C}$ was the moisture. So admontite lost its crystal water via a two-step process, where in the first 
TABLE 3: $\mathrm{B}_{2} \mathrm{O}_{3}$ contents of the synthesized magnesium borate minerals.

\begin{tabular}{|c|c|c|c|c|c|}
\hline \multirow{2}{*}{$\begin{array}{l}\text { Reaction temperature } \\
\left({ }^{\circ} \mathrm{C}\right)\end{array}$} & \multirow{2}{*}{$\begin{array}{l}\text { Reaction time } \\
\qquad(\min )\end{array}$} & \multicolumn{4}{|c|}{$\mathrm{B}_{2} \mathrm{O}_{3}(\%)$} \\
\hline & & Mc-T-H & Mc-T-B & Mc-Bx-H & Mc-Bx-B \\
\hline \multirow{4}{*}{60} & 30 & $51.21 \pm 1.87$ & $44.59 \pm 1.75$ & $45.73 \pm 2.73$ & $43.48 \pm 2.28$ \\
\hline & 60 & $55.39 \pm 1.37$ & $53.33 \pm 0.79$ & $45.89 \pm 2.51$ & $49.92 \pm 2.28$ \\
\hline & 120 & $52.54 \pm 0.67$ & $51.65 \pm 0.50$ & $45.09 \pm 1.82$ & $40.00 \pm 1.64$ \\
\hline & 240 & $53.65 \pm 2.16$ & $41.87 \pm 1.82$ & $45.48 \pm 2.83$ & $52.03 \pm 1.59$ \\
\hline \multirow{4}{*}{80} & 30 & $54.27 \pm 1.59$ & $50.27 \pm 2.29$ & $43.48 \pm 2.28$ & $46.86 \pm 1.14$ \\
\hline & 60 & $43.48 \pm 2.28$ & $54.04 \pm 1.37$ & $45.26 \pm 1.83$ & $50.89 \pm 0.91$ \\
\hline & 120 & $37.04 \pm 2.28$ & $54.42 \pm 2.00$ & $48.47 \pm 1.14$ & $44.87 \pm 1.55$ \\
\hline & 240 & $43.48 \pm 2.28$ & $54.30 \pm 0.67$ & $46.83 \pm 1.96$ & $45.25 \pm 1.59$ \\
\hline \multirow{4}{*}{100} & 30 & $53.92 \pm 1.79$ & $54.27 \pm 2.04$ & $43.48 \pm 2.28$ & $43.16 \pm 1.37$ \\
\hline & 60 & $53.18 \pm 0.42$ & $54.01 \pm 0.25$ & $51.92 \pm 2.28$ & $41.97 \pm 2.01$ \\
\hline & 120 & $54.24 \pm 1.83$ & $51.89 \pm 1.08$ & $50.40 \pm 2.05$ & $41.38 \pm 1.59$ \\
\hline & 240 & $53.65 \pm 2.16$ & $49.92 \pm 2.73$ & $43.48 \pm 2.28$ & $40.04 \pm 2.28$ \\
\hline
\end{tabular}
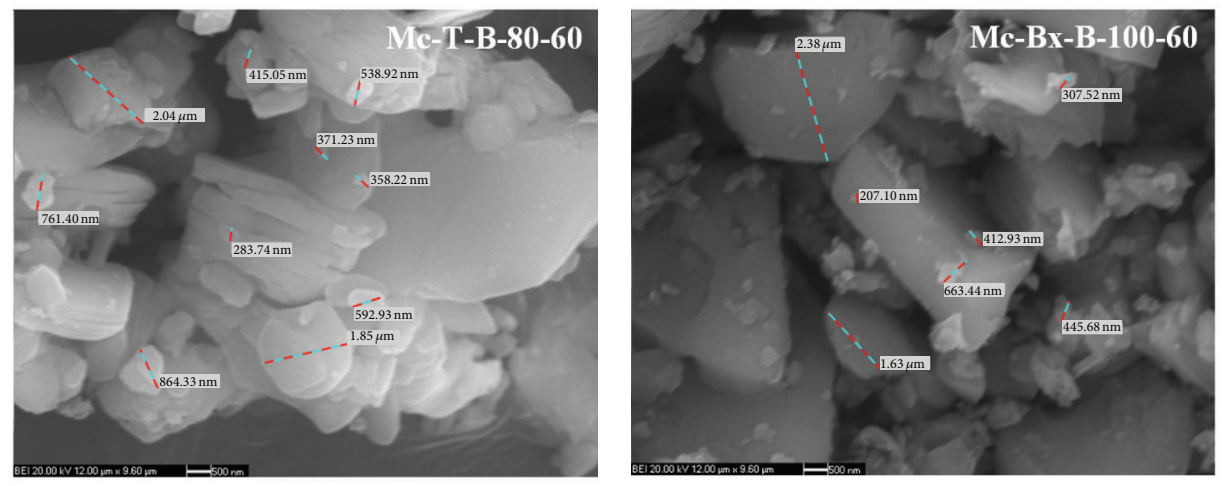

FIGURE 5: SEM surface morphology and the particle size of admontite minerals.

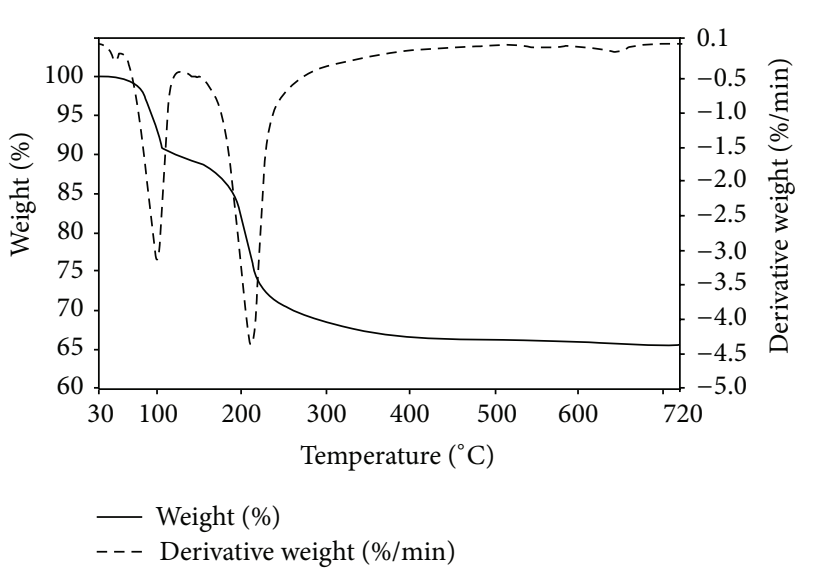

FIGURE 6: TG and DTG analyses of admontite mineral.

dehydration step the initial, peak, and final temperatures were seen as $59.47^{\circ} \mathrm{C}, 100.10^{\circ} \mathrm{C}$, and $129.45^{\circ} \mathrm{C}$. In the second step, initial, peak, and final temperatures were found as $129.45^{\circ} \mathrm{C}$, $212.06^{\circ} \mathrm{C}$, and $710.00^{\circ} \mathrm{C}$. Weight decreases were $9.965 \%$ and $24.130 \%$ for the first and second steps, respectively. Total weight loss was calculated as $34.095 \%$, which is close to theoretical structural water content $(33.60 \%)$ of admontite

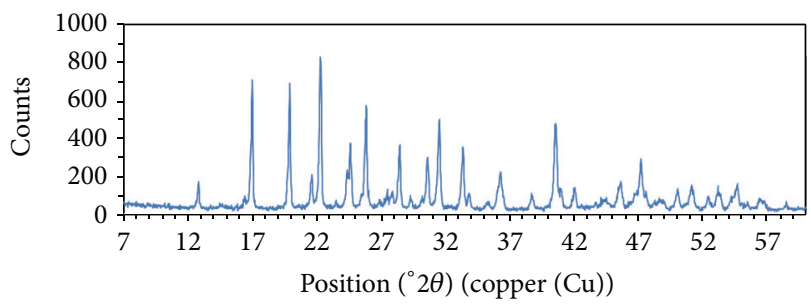

FIgURE 7: XRD pattern of $\mathrm{MgB}_{4} \mathrm{O}_{7}$.

mineral. So in the first dehydration step there was small moisture content of $0.495 \%$. According to the found data the dehydration steps of appeared as, which is in a mutual agreement with the study of Derun et al. [19]:

$$
\begin{gathered}
\mathrm{MgO}\left(\mathrm{B}_{2} \mathrm{O}_{3}\right)_{3} \cdot 7\left(\mathrm{H}_{2} \mathrm{O}\right) \\
\longrightarrow \mathrm{MgO}\left(\mathrm{B}_{2} \mathrm{O}_{3}\right)_{3} \cdot 5\left(\mathrm{H}_{2} \mathrm{O}\right)+2 \mathrm{H}_{2} \mathrm{O} \\
\mathrm{MgO}\left(\mathrm{B}_{2} \mathrm{O}_{3}\right)_{3} \cdot 5\left(\mathrm{H}_{2} \mathrm{O}\right) \longrightarrow \mathrm{MgO}\left(\mathrm{B}_{2} \mathrm{O}_{3}\right)_{3}+5 \mathrm{H}_{2} \mathrm{O}
\end{gathered}
$$

3.7. Thermal Conversion Results of the Synthesized Magnesium Borates. According to thermal conversion results, the calcined magnesium borate lost $33.62 \%$ of its weight. This result 

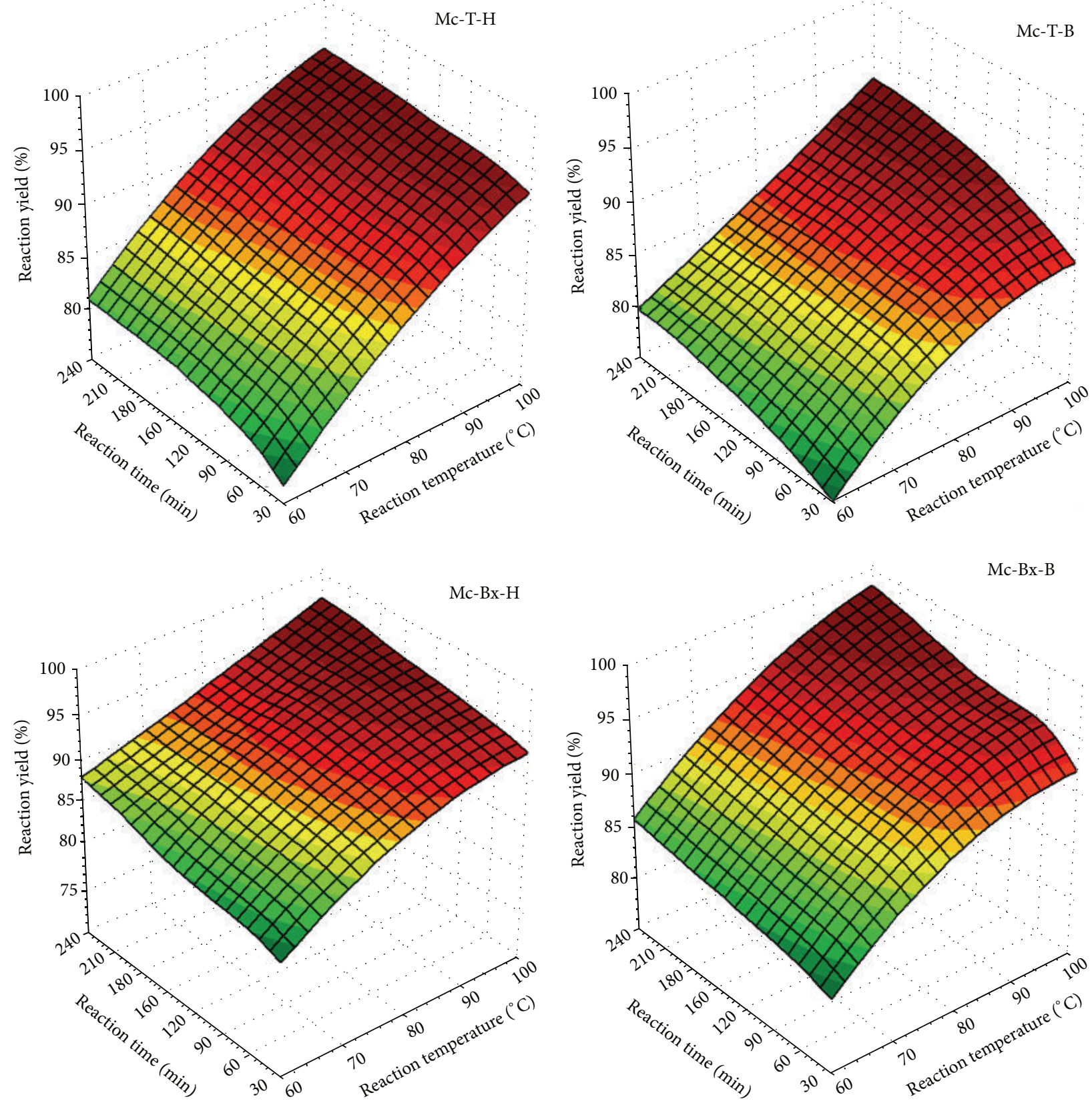

FIGURE 8: Reaction yields of synthesized admontite minerals.

conformed with the TG analyses and admontite's theoretical structural water content of $33.60 \%$. XRD results showed that the admontite mineral lost all of its structural water and turned to a dehydrated magnesium borate mineral $\mathrm{MgB}_{4} \mathrm{O}_{7}$ (pdf 00-031-0787). Before XRD analysis, the calcined admontite was washed with pure ethanol and dried at $40^{\circ} \mathrm{C}$ to remove $\mathrm{B}_{2} \mathrm{O}_{3}$ which occurred together with $\mathrm{MgB}_{4} \mathrm{O}_{7}$ during the calcination. The weight changes before and after leaching showed the equimolar $\mathrm{MgB}_{4} \mathrm{O}_{7}$ and $\mathrm{B}_{2} \mathrm{O}_{3}$ conversion.

The crystallographic data obtained from XRD are presented in Table 4 for admontite and $\mathrm{MgB}_{4} \mathrm{O}_{7}$. The XRD pattern of $\mathrm{MgB}_{4} \mathrm{O}_{7}$ is given in Figure 7 .
At Figure 7 the five major characteristic peaks of $\mathrm{MgB}_{4} \mathrm{O}_{7}$ are seen at $17^{\circ}, 20^{\circ}, 22^{\circ}, 26^{\circ}$, and $41^{\circ}$.

3.8. Yield Calculation of the Synthesized Magnesium Borates. Reaction yields increased with increasing reaction temperature and time for both sets which is shown in Figure 8. The yields were calculated between 76.2-95.2\%, 75.1-92.6\%, 82.897.2\%, and $82.0-98.7 \%$ for the sets of "Mc-T-H," "Mc-T-B," "Mc-Bx-H," and "Mc-Bx-B," respectively.

The pure admontite minerals yields were found as $85.9 \pm$ $0.9,85.0 \pm 0.6$, and $94.0 \pm 1.0 \%$ for the parameters of 
TABLE 4: Crystallographic data of synthesized magnesium borates.

\begin{tabular}{lc}
\hline Mineral name & Magnesium borate \\
\hline Pdf number & $00-031-0787$ \\
Chemical formula & $\mathrm{MgB}_{4} \mathrm{O}_{7}$ \\
Molecular weight $(\mathrm{g} / \mathrm{mole})$ & 179.55 \\
Crystal system & Orthorhombic \\
Space group & Pbca (number 61$)$ \\
$a(\AA)$ & 8.5960 \\
$b(\AA)$ & 13.7290 \\
$c(\AA)$ & 7.9560 \\
$\alpha\left(^{\circ}\right)$ & 90.00 \\
$\beta\left(^{\circ}\right)$ & 90.00 \\
$\gamma\left(^{\circ}\right)$ & 90.00 \\
$z$ & 8.00 \\
Density (calculated) $\left(\mathrm{g} \cdot \mathrm{cm}^{-3}\right)$ & 2.54 \\
\hline
\end{tabular}

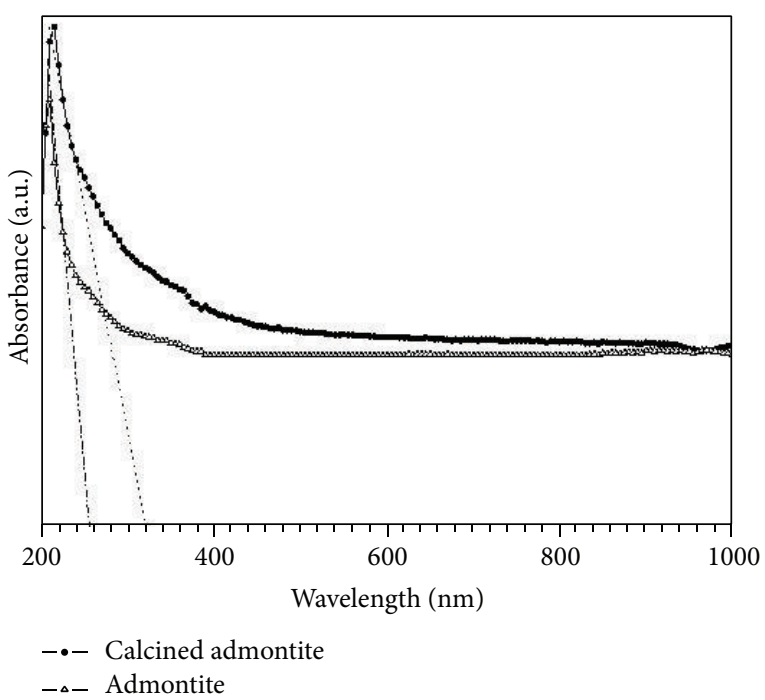

FIGURE 9: The optical absorption spectra of admontite and calcined admontite.

"Mc-Bx-B-60-240," "Mc-T-B-80-60," and “Mc-Bx-H-100-60," respectively.

3.9. Results of Electrical and Optical Measurements. The absorption spectra of the magnesium borate mineral of admontite were measured in the wavelength range of 200$1000 \mathrm{~nm}$ at room temperature. Figure 9 shows the optical absorption spectra of admontite and calcined admontite. The energy gap of the admontite and calcined admontite was determined from extrapolation of high energy part of absorption spectra as about $4.77 \mathrm{eV}$ and $4.13 \mathrm{eV}$, respectively.

Figure 10 shows the current voltage characteristics of the different magnesium borate compounds, which are coded with "Mc-Bx-H-100-60," "Mc-Bx-B-60-240," "Mc-T-B-8060 ," and calcined admontite. The resistivity of the compounds is derived to be $3.07 \times 10^{7}, 1.09 \times 10^{7}, 1.18 \times 10^{8}$, and $1.51 \times 10^{7} \Omega \mathrm{m}$, respectively, which are obtained from the

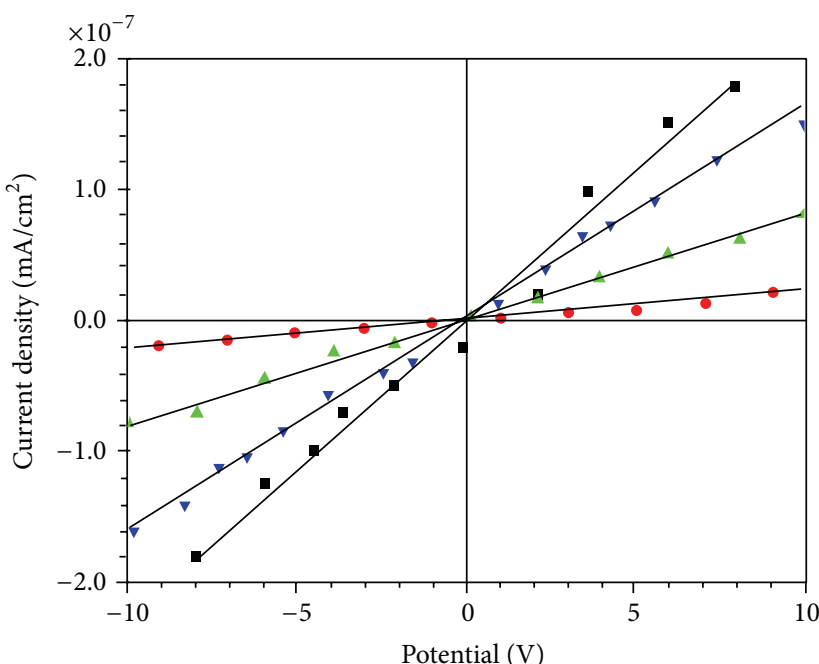

- Mc-Bx-B-60-240

A Mc-Bx-H-100-60

- Mc-T-B-80-60

$\checkmark$ Calcined admontite

Figure 10: The current voltage characteristics of different magnesium borate compounds.

current voltage curves. The resistivities of the compounds were changed in the range of $10^{7}-10^{8} \Omega \mathrm{m}$.

\section{Discussion and Conclusions}

In this study for the approach of green chemistry the hydrothermal method at lower reaction temperature and reaction time is conducted in the synthesis of magnesium borates from sodium borates. From the results of this study, contrary to the previous studies, even at $60^{\circ} \mathrm{C}$ and 30 -minute reaction time pure admontite synthesis was accomplished with high crystal scores. Derun et al. [19] reported the highest crystal score as 61 although in this study higher crystal scores were reached even when reducing reaction temperatures and furthermore the yield of obtained synthesized compounds ranged between 75.1 and $98.7 \%$. FT-IR and Raman spectroscopy results showed that the products had characteristic peaks of magnesium borates in both infrared and visible regions. According to SEM results, the particle sizes of synthesized magnesium borate minerals were between $2.38 \mu \mathrm{m}$ and $207.10 \mathrm{~nm}$.

Also, the electrical conductivity of the magnesium borate compounds was determined in the range of $10^{-7}-10^{-8}(\Omega \mathrm{m})^{-1}$ with the content of pure admontite minerals yields in the range of $85-94 \%$. Resistivity measurement of bulk magnesium borate has not been studied and conductivity of magnesium borate nanowires is calculated to be about $10^{-4}(\Omega \mathrm{m})^{-1}$ in literature [16]; the wide difference in the conductivity of the magnesium borate obtained by Li et al. and the present study comes from the content of structural water inside the magnesium borates, where in this study $\mathrm{MgO}\left(\mathrm{B}_{2} \mathrm{O}_{3}\right)_{3} \cdot 7\left(\mathrm{H}_{2} \mathrm{O}\right)$ type of magnesium borate is synthesized; on the contrary $\mathrm{Li}$ et al. synthesized $\mathrm{Mg}_{2} \mathrm{~B}_{2} \mathrm{O}_{5}$ which is a dehydrated type of magnesium borate. 
The energy band gaps of admontite and calcined admontite were determined to be about $4.77 \mathrm{eV}$ and $4.13 \mathrm{eV}$, respectively, where in literature Kumari et al. [3] calculated the energy band gap of magnesium borate to be $4.72 \mathrm{eV}$, which is in mutual agreement with the obtained energy gap values.

\section{Conflict of Interests}

The authors declare that there is no conflict of interests regarding the publication of this paper.

\section{Acknowledgment}

This research has been supported by Yildiz Technical University Scientific Research Projects Coordination Department with Project number of 2013-07-01-GEP04.

\section{References}

[1] L. Dou, J. Zhong, and H. Wang, "Preparation and characterization of magnesium borate for special glass," Physica Scripta, vol. 139, Article ID 014010, 2010.

[2] S. Li, D. Xu, H. Shen, J. Zhou, and Y. Fan, "Synthesis and Raman properties of magnesium borate micro/nanorods," Materials Research Bulletin, vol. 47, no. 11, pp. 3650-3653, 2012.

[3] L. Kumari, W. Z. Li, S. Kulkarni et al., "Effect of surfactants on the structure and morphology of magnesium borate hydroxide nanowhiskers synthesized by hydrothermal route," Nanoscale Research Letters, vol. 5, no. 1, pp. 149-157, 2010.

[4] B. Xu, T. Li, Y. Zhang, Z. Zhang, X. Liu, and J. Zhao, "New synthetic route and characterization of magnesium borate nanorods," Crystal Growth \& Design, vol. 8, no. 4, pp. 1218-1222, 2008.

[5] D. I. Shahare, S. J. Dhoble, and S. V. Moharil, "Preparation and characterization of magnesium-borate phosphor," Journal of Materials Science Letters, vol. 12, no. 23, pp. 1873-1874, 1993.

[6] Z. S. Hu, R. Lai, F. Lou et al., "Preparation and tribological properties of nanometer magnesium borate as lubricating oil additive," Wear, vol. 252, no. 5-6, pp. 370-374, 2002.

[7] Y. Kashiwada and Y. Furuhata, "Domains in magnesium pyroborates," Physica Status Solidi A, vol. 36, no. 1, pp. k29-k31, 1976.

[8] H. Wang, G. Jia, Y. Wang et al., "Crystal growth and spectral properties of pure and $\mathrm{Co}^{+}$-doped $\mathrm{Mg}_{3} \mathrm{~B}_{2} \mathrm{O}_{6}$ crystal," Optical Materials, vol. 29, no. 12, pp. 1635-1639, 2007.

[9] C. Furetta, G. Kitis, P. S. Weng, and T. C. Chu, "Thermoluminescence characteristics of $\mathrm{MgB}_{4} \mathrm{O}_{7}$ : Dy,Na," Nuclear Instruments and Methods in Physics Research A, vol. 420, no. 3, pp. 441-445, 1999.

[10] W. Zhu, Q. Zhang, L. Xiang et al., "Flux-assisted thermal conversion route to pore-free high crystallinity magnesium borate nanowhiskers at a relatively low temperature," Crystal Growth and Design, vol. 8, no. 8, pp. 2938-2949, 2008.

[11] W. Zhu, L. Xiang, T. He, and S. Zhu, "Hydrothermal synthesis and characterization of magnesium borate hydroxide nanowhiskers," Chemistry Letters, vol. 35, no. 10, pp. 1158-1159, 2006.

[12] W. Zhu, X. Zhang, L. Xiang, and S. Zhu, "Hydrothermal formation of the head-to-head coalesced szaibelyite $\mathrm{MgBO}_{2}(\mathrm{OH})$ nanowires," Nanoscale Research Letters, vol. 4, no. 7, pp. 724-731, 2009.
[13] M. Y. Masoomi and A. Morsali, "Applications of metal-organic coordination polymers as precursors for preparation of nanomaterials," Coordination Chemistry Reviews, vol. 256, no. 23-24, pp. 2921-2943, 2012.

[14] W. Zhu, G. Li, Q. Zhang, L. Xiang, and S. Zhu, "Hydrothermal mass production of $\mathrm{MgBO}_{2}(\mathrm{OH})$ nanowhiskers and subsequent thermal conversion to $\mathrm{Mg}_{2} \mathrm{~B}_{2} \mathrm{O}_{5}$ nanorods for biaxially oriented polypropylene resins reinforcement," Powder Technology, vol. 203, no. 2, pp. 265-271, 2010.

[15] E. M. Elssfah, A. Elsanousi, J. Zhang, H. S. Song, and C. Tang, "Synthesis of magnesium borate nanorods," Materials Letters, vol. 61, no. 22, pp. 4358-4361, 2007.

[16] Y. Li, Z. Fan, J. G. Lu, and R. P. H. Chang, "Synthesis of magnesium borate $\left(\mathrm{Mg}_{2} \mathrm{~B}_{2} \mathrm{O}_{5}\right)$ nanowires by chemical vapor deposition method," Chemistry of Materials, vol. 16, no. 13, pp. 25122514,2004

[17] G. Wang, K. Wang, J. Hou, Y. Wang, and C. Kong, "Preparation of magnesium borate nanomaterials by hydrothermal route," Advanced Materials Research, vol. 320, pp. 642-646, 2011.

[18] L. Zhihong and H. Mancheng, "New synthetic method and thermochemistry of szaibelyite," Thermochimica Acta, vol. 411, no. 1, pp. 27-29, 2004.

[19] E. M. Derun, A. S. Kipcak, F. T. Senberber, and M. S. Yilmaz, "Characterization and thermal dehydration kinetics of admontite mineral hydrothermally synthesized from magnesium oxide and boric acid precursor," Research on Chemical Intermediates, 2013.

[20] E. M. Derun and F. T. Senberber, "Characterization and thermal dehydration kinetics of highly crystalline mcallisterite, synthesized at low temperatures," The Scientific World Journal, vol. 2014, Article ID 985185, 10 pages, 2014.

[21] M. Yildirim, A. S. Kipcak, E. M. Derun, and S. Piskin, "Characterization of nano-scale magnesium borates hydrothermally synthesized from $\mathrm{Na}_{2} \mathrm{~B}_{4} \mathrm{O}_{7} \cdot 5 \mathrm{H}_{2} \mathrm{O}, \mathrm{MgCl}_{2} \cdot 6 \mathrm{H}_{2} \mathrm{O}$ and $\mathrm{H}_{3} \mathrm{BO}_{3}$ at $80^{\circ} \mathrm{C}$," in Proceedings of the Advanced Materials World Congress (AMWC '13), Cesme, Turkey, September 2013.

[22] W. D. Cheng, H. Zhang, F. K. Zheng, J. T. Chen, Q. E. Zhang, and R. Pandey, "Electronic structures and linear optics of $\mathrm{A}_{2} \mathrm{~B}_{2} \mathrm{O}_{5}$ (A $=\mathrm{Mg}, \mathrm{Ca}, \mathrm{Sr}$ ) pyroborates," Chemistry of Materials, vol. 12, no. 12, pp. 3591-3594, 2000.

[23] A. F. Qasrawi, T. S. Kayed, A. Mergen, and M. Gürü, "Synthesis and characterization of $\mathrm{Mg}_{2} \mathrm{~B}_{2} \mathrm{O}_{5}$, Materials Research Bulletin, vol. 40, no. 4, pp. 583-589, 2005.

[24] J. Yongzhong, G. Shiyang, X. Shuping, and L. Jun, "FT-IR spectroscopy of supersaturated aqueous solutions of magnesium borate," Spectrochimica Acta A: Molecular and Biomolecular Spectroscopy, vol. 56, no. 7, pp. 1291-1297, 2000.

[25] M. Y. Masoomi and A. Morsali, "Morphological study and potential applications of nano metal-organic coordination polymers," RSC Advances, vol. 3, pp. 19191-19218, 2013.

[26] H. S. Fogler, Element of Chemical Reaction Engineering, Prentice-Hall, Upper Saddle River, NJ, USA, 3rd edition, 1999. 

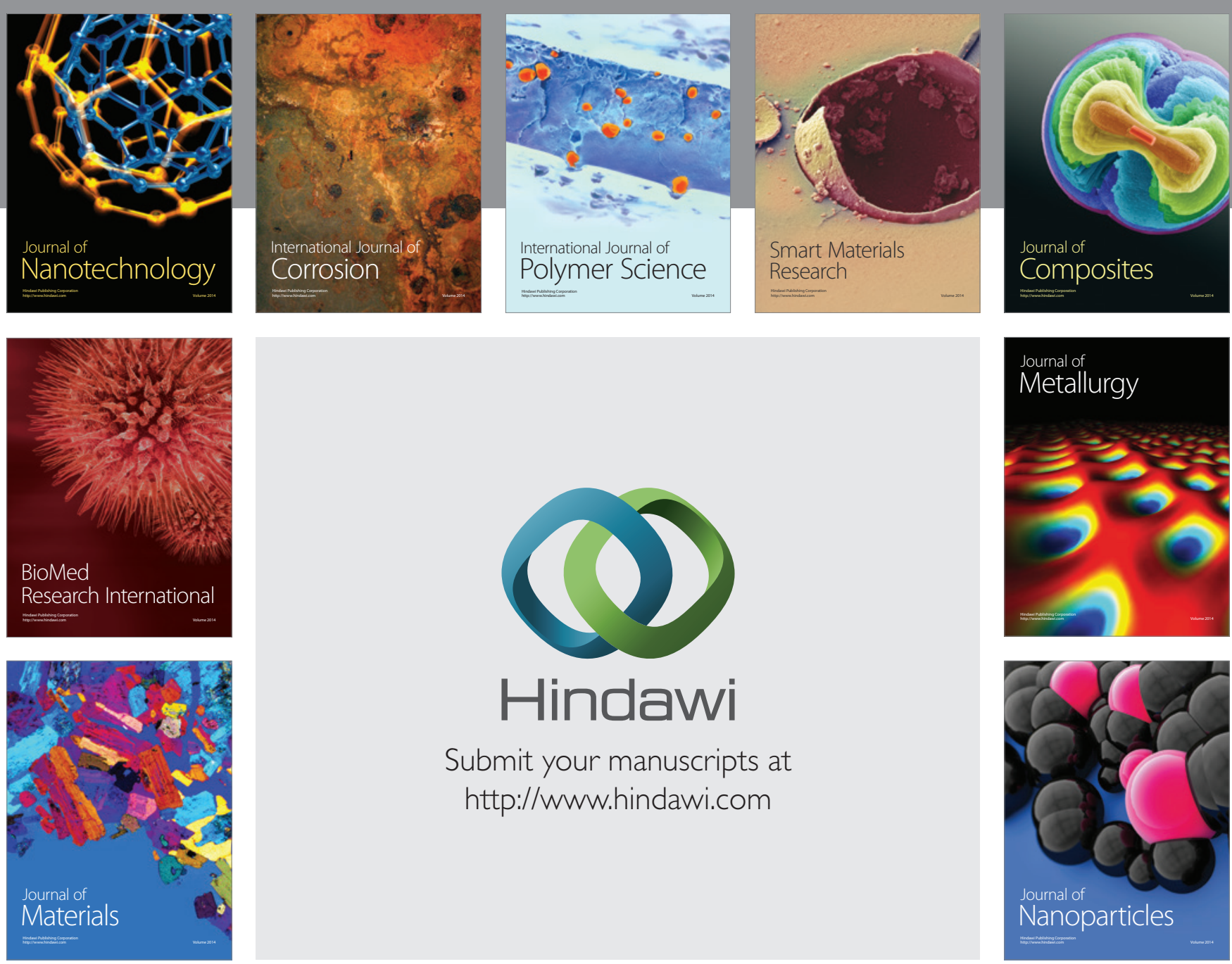

Submit your manuscripts at http://www.hindawi.com
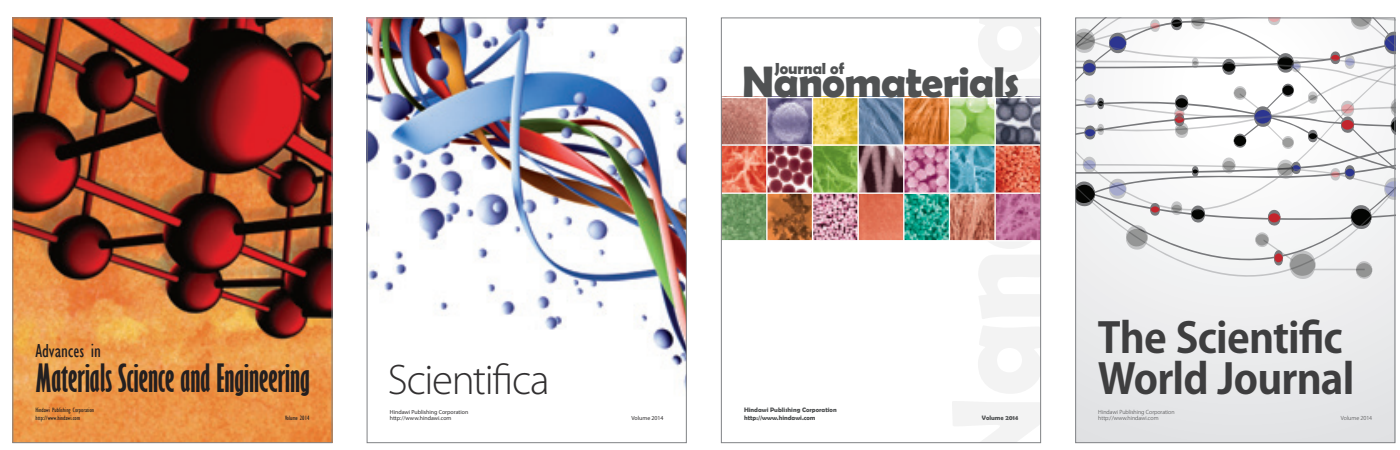

\section{The Scientific World Journal}
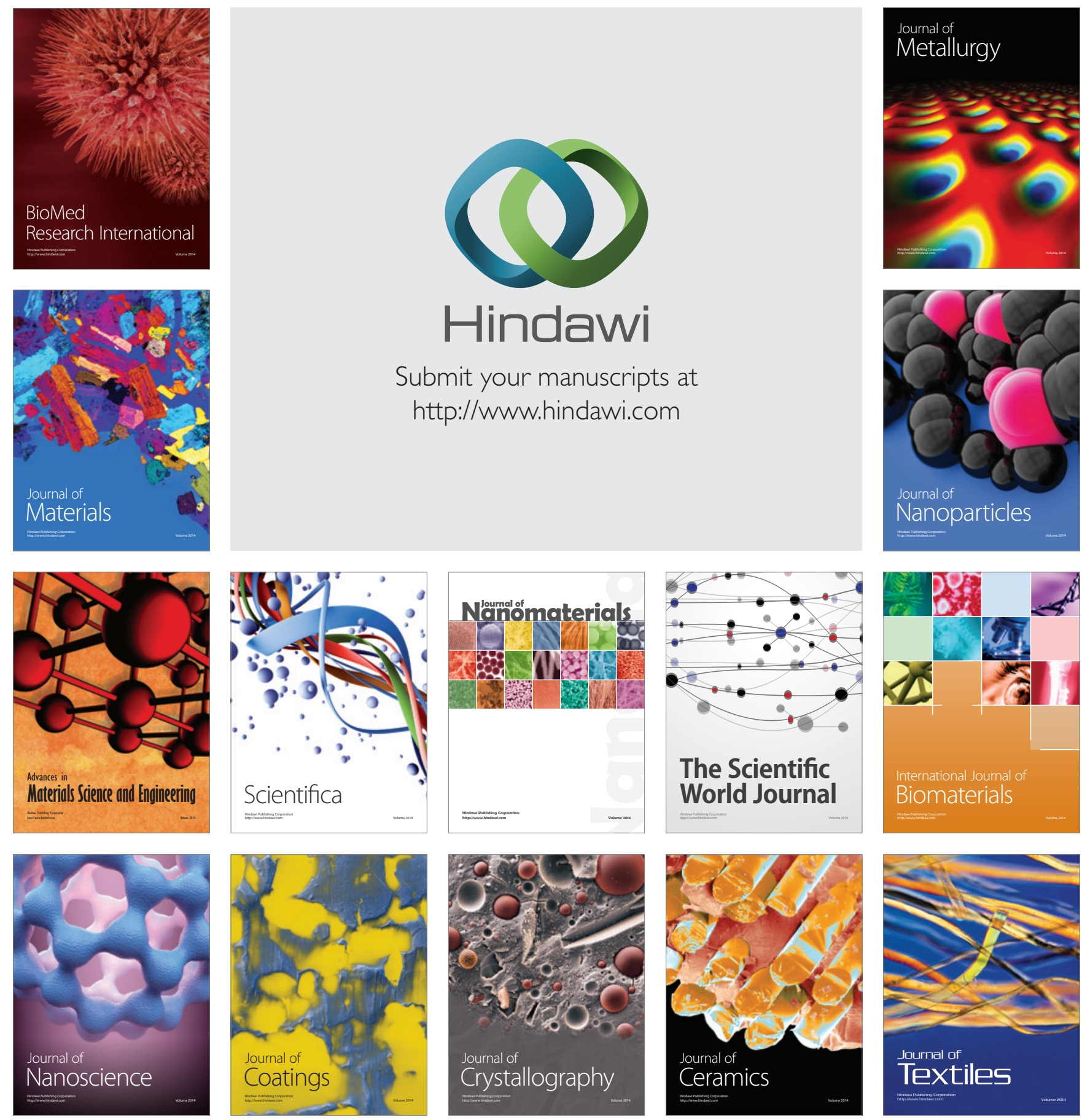